\title{
REMOVAL OF CADMIUM, LEAD AND ORGANIC LOAD FROM WASTEWATER USING BIOGENIC SULFIDE UNDER ANAEROBIC CONDITIONS
}

\author{
Abdelrazek $^{*}$, M. A. and Abdel-Hadi ${ }^{* *}$, M. A.
}

\section{ABSTRACT}

The influent of the wastewater treatment plant in Ismailia - Egypt loaded with many species of heavy metals, since no separation between industrial and municipal wastewaters because the plant was not designed to remove these metals. The objective of this study was to apply a method able to remove aforementioned metals with biomass concurrently and characterized to be cheap and effective. The removal of heavy metals such as lead, cadmium and minimize the volume of biomass simultaneously was achieved by using bench-scale biogas digester (vertical type) under anaerobic conditions and optimum temperature within the mesophilic condition $38{ }^{\circ} \mathrm{C}$. The treatments of this work carried out on two phases; the first phase was conducted in the absence of gypsum adding (control treatments) and the second was performed with adding gypsum at a dose equal to $5 \mathrm{gl}^{-1}$ (gypsum treatments) with a fermentation time of 20 days. These treatments carried out on the slurry, which was the end residue in the treatment lagoons in Ismailia wastewater treatment plant. This slurry was supplemented with the studied metals. The objective behind adding gypsum was to reduce by native species of sulphate reducing bacteria (SRB) and then produce biogenic sulfide, which used in precipitation of these metals as sulfides and their loss with the wasted biomass. The results showed that the removal efficiency for both $\mathrm{Cd}$ and $\mathrm{Pb}$ metals increased with decrease the initial concentration of them. Since, the removal levels of both metals for gypsum treatments were $>99 \%$ at $\mathrm{Cd}$ and $\mathrm{Pb}$ with initial concentrations not exceed over 120 and $150 \mathrm{mgl}^{-1}$, respectively. By comparison with control treatments at initial concentrations of $\mathrm{Cd}$ and $\mathrm{Pb}$ not exceed over 60 and $75 \mathrm{mgl}^{-1}$, respectively, the removal efficiency reached $>99 \%$ for $\mathrm{Cd}$ and $98.9 \%$ for $\mathrm{Pb}$.

\footnotetext{
* Lecturer of Soil and Water Dep., Fac. of Agr., Suez Canal Univ.

*** Associate Prof. of Agr. Eng. Dep., Fac. of Agr., Suez Canal Univ., 41522 Ismailia, Egypt.
} 
The $p H$ values for all gypsum treatment were around $p H 7$. Furthermore, the removal of total solids for the gypsum treatments reached over $84 \%$ for the most treatments at the end of the fermentation time. The reaction of $\mathrm{Cd}$ and $\mathrm{Pb}$ belongs to the second-order kinetic model. It can be concluded that, the adding gypsum under previous conditions as a treatment process can be an effective approach to reuse this kind of wastewater safely in many purposes especially in irrigation.

Key words: Wastewater, Anaerobic digestion, Lead, Cadmium, Gypsum, Biogenic sulfide, Kinetics

\section{INTRODUCTION}

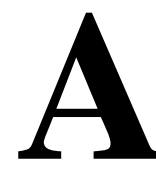

lvarez et al. (2007) pointed out that precipitating the metal sulphide with the biomass means that the precipitated metals are lost with the wasted biomass, although they can be recovered from the bio-sludge. They used a two-stage process, which separated out the metal precipitation and biological sulphate reduction steps. Mine waters and industrial effluents that contain high sulphate and metal concentrations can be treated using a combination of bacterial sulphate reduction to generate sulphide, followed by removal of the metals as metal sulphide precipitates. Many studies have been carried out in this area of application. Since most of the Acid Mine Drainage treatment processes produced amorphous metal sulphide precipitates, it is important to understand that the solubility differences between these and the solubilities of the crystalline metal sulphide that are most often reported in the literature. The environmental implications of producing a more soluble metal sulphide are often not taken into account. Gammons and Frandzen (2001) have started in a paper that points out the differences between the theoretical and measured solubilities of metal sulphide removed at a treatment wetland. Removal and recovery of metals as metal sulphide, when it comes to sludge volume, reusability of the sludge and effluent quality, precipitation of metals with sulphide is superior to precipitation as hydroxides. It has many advantages over lime precipitation such as:

- High reactivity of sulphide with heavy-metal ions and very low solubility of the resulting metal sulphide over a broad $\mathrm{pH}$ range resulting in lower effluent concentrations. 
- Sulphide precipitation, unlike hydroxide precipitation, is relatively insensitive to the presence of complexes and most chelating agents.

- A high degree of selective metal precipitation is possible with sulphide, contrary to hydroxide precipitation.

- Metal sulphide sludges generally are more dense and stable than metal hydroxide sludges, exhibiting better thickening and dewatering characteristics than the corresponding metal hydroxide sludge, which facilitates further processing.

Previous objections against the use of sulphide, i.e. that it is toxic and corrosive, do not hold anymore because of the application of adequate safety measures, and the use of modern corrosion-resistant construction materials (plastics) eliminate these disadvantages. In the remainder of this paper, technology will be described to produce sulphide on-site and on-demand using biotechnology. This eliminates the hazards and costs that accompany the transport, handling and storage of chemical sulphide. Sulfate reducing Bacteria SRB is anaerobes characterized by their ability to perform dissimulator sulfate reduction with the simultaneous oxidation of the organic substrates (Postgate, 1984). Lead is a toxic metal to humans, aquatic fauna and livestock; its toxicity in humans includes hypertension and brain damage. Cadmium is a highly toxic element that, in humans, can cause serious damage to kidneys and bones; and is probably best known for its association with itai-itai disease (Wase and Forster, 1995).

The influent of wastewater treatment plant in Ismailia - Egypt, loaded by many species of heavy metals, i.e. since; no separation between industrial and municipal wastewaters is performed because the plant was not designed to remove these metals. Thus, we need to a method able to remove these metals with biomass concurrently, characterize by its cheapest and effective. The objectives of this study were to investigate removal of $\mathrm{Cd}, \mathrm{Pb}$ and minimize the volume of biomass simultaneously under anaerobic digestion by adding gypsum to the slurry, which was supplemented with the studied metals. After that, gypsum was reduced by sulphate reducing bacteria (SRB) to produce biogenic sulfide and then these metals were precipitated as sulfides which can be losable with the wasted biomass.

$$
4 \mathrm{H}_{2}+\mathrm{SO}_{4}^{-2} \ldots \ldots . .{ }^{\mathrm{SRB}} \ldots \ldots \ldots>4 \mathrm{H}^{+}+\mathrm{HS}^{-}+4 \mathrm{H}_{2} \mathrm{O}+\mathrm{SRB}
$$




\section{MATERIALS AND METHODS}

\section{Bench-scale biogas digester}

A bench-scale of cylindrical biogas digester (vertical type) is shown in Fig. (1). Three verticals biogas digesters were constructed at the Agricultural Engineering Department, Faculty of Agriculture, SuezCanal University. Each digester was fabricated from galvanized steel sheet of $1.5 \mathrm{~mm}$ thickness, $45 \mathrm{~cm}$ long and $25 \mathrm{~cm}$ diameter with total capacity of 22 liters and digestion volume of 20 liters, and it has a PVC inlet and outlet tubes of $50.8 \mathrm{~mm}$ diameter for feeding and rejecting the digested materials, respectively. To follow up the digestion processes, orifice for releasing the produced gas provided to the digester. To measure $\mathrm{pH}$ and temperature an inlet tube was used. A hasp mixer was mounted with the biogas digester and adjusted automatically at 2 minutes every half an hour, meanwhile a thermostatic heating unit provided the digester with a pump to adjust temperature selector. The temperature of the mixture adjusted within the mesophilic condition $\left(38^{\circ} \mathrm{C}\right)$.

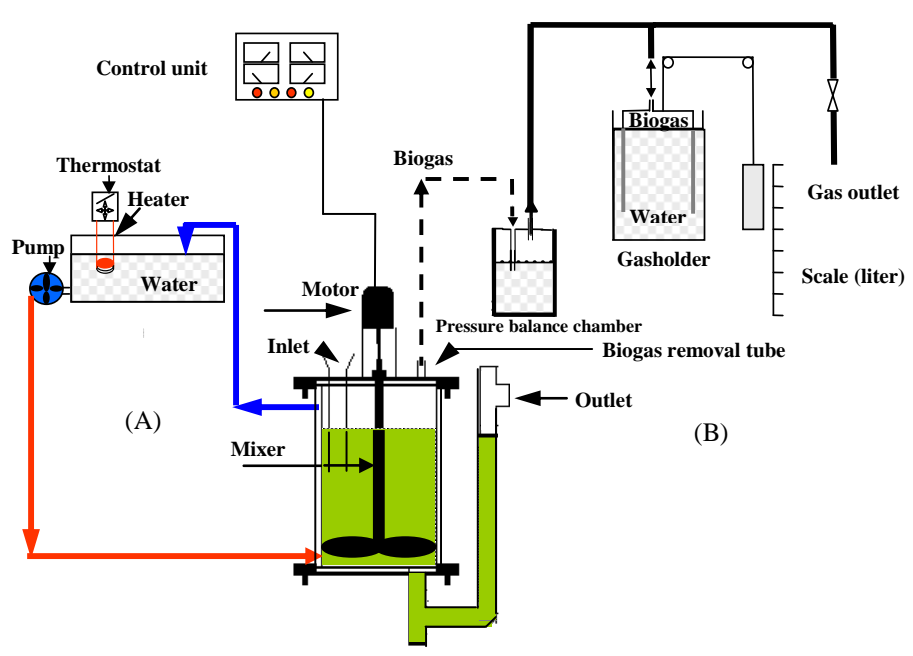

Fig. 1: Schematic diagram of vertical bench-scale biogas digester.

A thermostatic electrical heater and a centrifugal pump, operated by 90 Watt motor, assembled with an insulated water tank to form the heating 
unit beside the close cycle serpentine as shown in Fig. (1, A). Copper tube of $7.5 \mathrm{~m}$ length, (9.53 and $8.3 \mathrm{~mm}$ outer and inner diameters) serpentine was coiled around the digester which was insulated using $25.4 \mathrm{~mm}$ thick polystyrene slabs (foam) to create a stable temperature water jacket around the digester. The digester was feeding by the slurry, which was the end residue in the lagoons in Ismailia wastewater treatment plant. This slurry was supplemented with the studied metals by adding over concentrations of $\mathrm{Cd}$ and $\mathrm{Pb}$ to reach the initial concentrations to be as shown in Table (1). The treatments of this work were carried out in two phases; the first phase was conducted in the absence of gypsum (control treatments), and the second was carried out with adding gypsum (gypsum treatments). The fermentation time for each treatment was 20 days, and the sampling was every two days from the starting to the end of the treatment within the reactors. The samples were taken by plastic syringes and were kept in an icebox till to reach the lab to carry on which some analyses, viz. total solids (TS), volatile solids (VS), total $\mathrm{SO}_{4}{ }^{-2}$, total sulphide and the residual concentrations of $\mathrm{Pb}$ and $\mathrm{Cd}$.

Table 1: The initial concentrations of $\mathrm{Cd}$ and $\mathrm{Pb}$ in the slurry, $\mathrm{mgl}^{-1}$.

\begin{tabular}{lll}
\hline Treatments & Cd & $\mathrm{Pb}$ \\
\hline T1 & 20 & 25 \\
T2 & 40 & 50 \\
T3 & 60 & 75 \\
T4 & 80 & 100 \\
T5 & 100 & 125 \\
T6 & 120 & 150 \\
T7 & 140 & 175 \\
T8 & 160 & 200 \\
\hline
\end{tabular}

*These treatments were conducted without adding gypsum (control) and repeated with adding gypsum by dose $5 \mathrm{gl}^{-1}$.

In this work the direct inoculation of SRB was not used but depended on supporting the native species (inside this slurry) to growth by fulfillment the optimum conditions of $\mathrm{pH}$, temperature, substrate and keeping the anaerobic conditions. The depletion of $\mathrm{SO}_{4}{ }^{-2}$ and the increasing of sulfide 
concentrations in the gypsum treatments comparing with the control treatment was taken as an indicator on SRB activity inside the reactors.

Table 2: Physical and chemical characteristics of the end slurry of Ismailia wastewater treatment plant.

\begin{tabular}{ccccccc}
\hline $\mathrm{TS}$ & $\mathrm{VS}$ & $\mathrm{Cd}$ & $\mathrm{Pb}$ & $\mathrm{SO}_{4}^{-2}$ & $\mathrm{EC}$ & $\mathrm{pH}$ \\
\hline $\mathrm{gl}^{-1}$ & & & $\mathrm{mgl}^{-1}$ & & $\left(\mathrm{dSm}^{-1}\right)$ & \\
\hline 38.99 & 2.95 & 1.14 & 10.50 & 42.6 & 1.43 & 7.02 \\
\hline
\end{tabular}

TS $=$ total solids, $\mathbf{V S}=$ volatile solids

\section{Analytical methods and Instrumentation}

\section{Temperature and $\mathrm{pH}$}

The temperature and $\mathrm{pH}$ values of the slurry inside the bench-scale digesters were measured regularly every two days using Jenway $\mathrm{pH}$ hand held meter model $370 \mathrm{pH} / \mathrm{mv}$. The temperature of slurry inside digester was adjusted within the mesophilic condition $\left(38{ }^{\circ} \mathrm{C}\right)$. Dissolved sulfide was measured immediately after sampling using the methylene blue method (Fischer, 1883). Sulfate was measured by turbidimetric method according to the (APHA, 1980). TS and VS were measured according to APHA (1992). These parameters were determined for the gypsum treatments only. The values of residual concentration of sulfate and sulphide were corrected by subtracting the control treatment values. The residual concentrations of $\mathrm{Cd}$ and $\mathrm{Pb}$ in the filtrates were measured for the two types of the treatments by Atomic Absorption Spectroscopy (Perkin-Elmer, AAS, Flame, Series 711838 v1.26) according to (Skoog et al., 1992).

\section{Kinetic models}

Kinetic studies of metal removal in the control and gypsum treatments were developed in order to determine the fit kinetic model of the removal reaction of the studied metals. Two different kinetic models were applied in this work according to (Lagergren, 1898).

The lineraized form of the first-order model is generally expressed as:

$$
\ln (\mathrm{qe}-\mathrm{qt})=\ln \mathrm{qe}-\mathrm{k}_{1} \mathrm{t} \text {. }
$$


Where qe $(\mathrm{mg} / \mathrm{g})$ is the amount of metal ions adsorbed at equilibrium and qt $(\mathrm{mg} / \mathrm{g})$ is the amount of metal ions adsorbed at a particular time $\mathrm{t}$ (min), respectively. The values of $\mathrm{k}_{1}$ can be obtained from the slope of the plot of $\log (\mathrm{qe}-\mathrm{qt}$ ) versus t. The validity of the first-order kinetics and hence the Lagergren equation could be tested by comparing qe values obtained from the intercepts of the plots with those obtained. If the validity is weak, the kinetics can be tested for following second-order mechanism (Ho et al., 2001).

The lineraized form of the second-order model is generally expressed as:

$$
\mathrm{t} / \mathrm{q}_{\mathrm{t}}=\left(1 / \mathrm{k}_{2} \mathrm{q}_{\mathrm{e}}^{2}\right)+\left(1 / \mathrm{q}_{\mathrm{e}}\right) \mathrm{t}
$$

Where $\mathrm{K}_{2}\left(\mathrm{mg} \cdot \mathrm{g}^{-1} \mathrm{~min}^{-1}\right)$ is the rate constant of the second order equation.

Scanning electron microscopy (SEM) with an energy dispersive X-Ray (EDX)

The morphology and microstructure of solid residue samples for control and gypsum treatments after their reactions with heavy metals cations were studied by using scanning electron microscopy (SEM) technique. The powdered samples were converted to disc and coated by gold using vapor gold; a Philips XL30 attached to EDAX unit, wit-accelerating voltage up to $30 \mathrm{KV}$ and magnification $50000 \mathrm{X}$ was used. Scanning electron microscopy (SEM) technique by JEOL Scanning electron microscopy JSM-5600 attached to an energy dispersive X-Ray (EDX).

\section{http://www.jeolusa.com}

\section{Statistical analysis}

The SPSS statistical package, version 16.0 (SPSS Inc., Michigan, USA), was used for the statistical analysis.

\section{RESULTS AND DISCUSSION}

\section{Removal efficiency of $\mathrm{Cd}$ and $\mathrm{Pb}$ for control and gypsum treatments}

Fig. (2) shows that the higher initial concentrations of $\mathrm{Cd}$ and $\mathrm{Pb}$ led to higher of their residual concentrations and the lower was in removal percentages for all treatments. Although, by passing the fermentation time, the residual concentrations of $\mathrm{Cd}$ and $\mathrm{Pb}$ proved to be decreased and this was true for all treatments. 

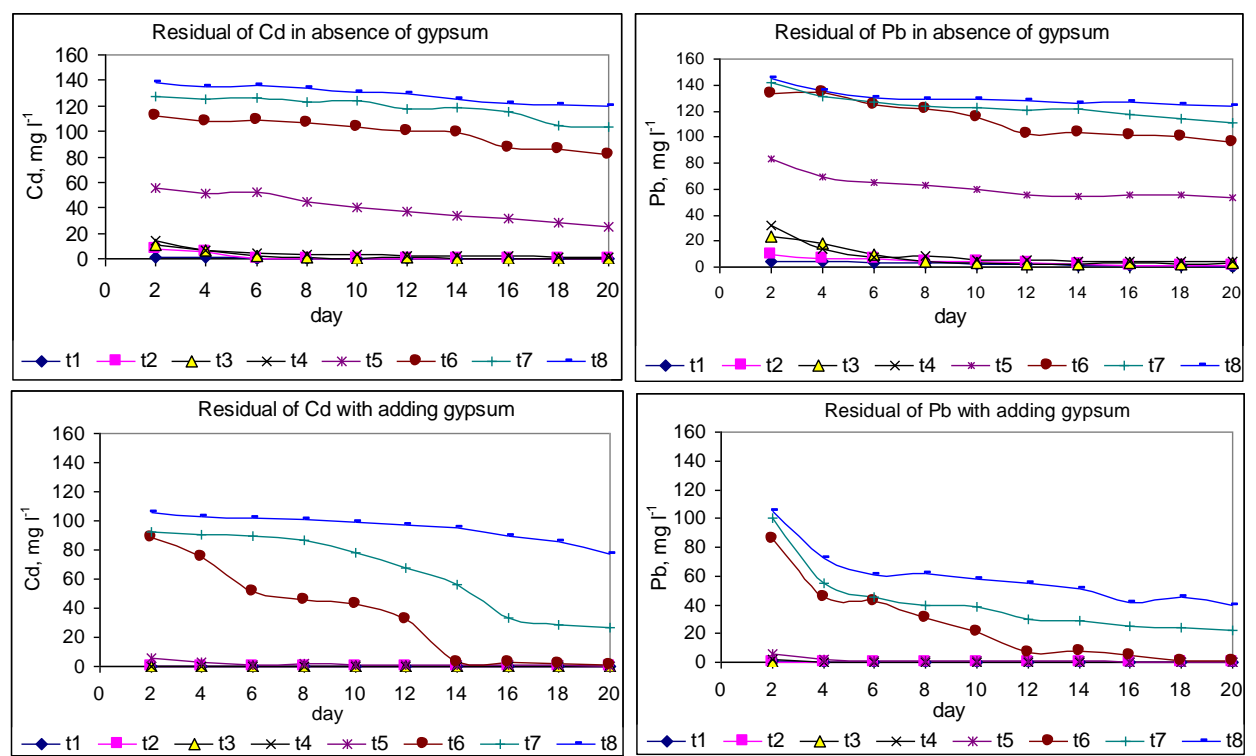

Fig. 2: Effect of fermentation time on the residual concentrations of $\mathrm{Cd}$ and $\mathrm{Pb}$ for control and gypsum treatments.

Fig. (3) explains that the removal efficiency level for both $\mathrm{Cd}$ and $\mathrm{Pb}$ metals increased with decrease the initial concentration for them in all treatments. Since this level was $>99 \%$ for gypsum treatment when $\mathrm{Cd}$ and $\mathrm{Pb}$ with initial concentrations not exceeded over 120 and $150 \mathrm{mgl}^{-1}$ (T6), respectively. By comparison, these levels for control treatment were (>99\% for $\mathrm{Cd}$ and $989 \%$ for $\mathrm{Pb}$ ) when initial concentrations of $\mathrm{Cd}$ and $\mathrm{Pb}$ not exceeded over 60 and $75 \mathrm{mgl}^{-1}$ (T3), respectively. Whereas the last four control treatments, which be having high initial concentrations of two metals, characterized by decreasing ability of their solids in which to laden these metals, but the position with adding gypsum was changed. Since in the absence of gypsum the pathway of removal depended on sorption of metals on solids that is existence actually in the slurry. The surfaces of these solids are limited, but with adding gypsum increase the precipitation process was achieved using biogenic sulfide. The sorption of heavy metals occurs on the solid fraction, either biomass or inert particulate matter (Shin et al., 1997). The sorption of heavy metals on to these biomaterials is attributed to their constituents, which are mainly proteins, carbohydrates, and phenolis 
compounds, which contain functional groups such as carboxyl, hydroxyl and amine that are responsible for the binding of metal ions (Al-Asheh and Duvnjak, 1998).
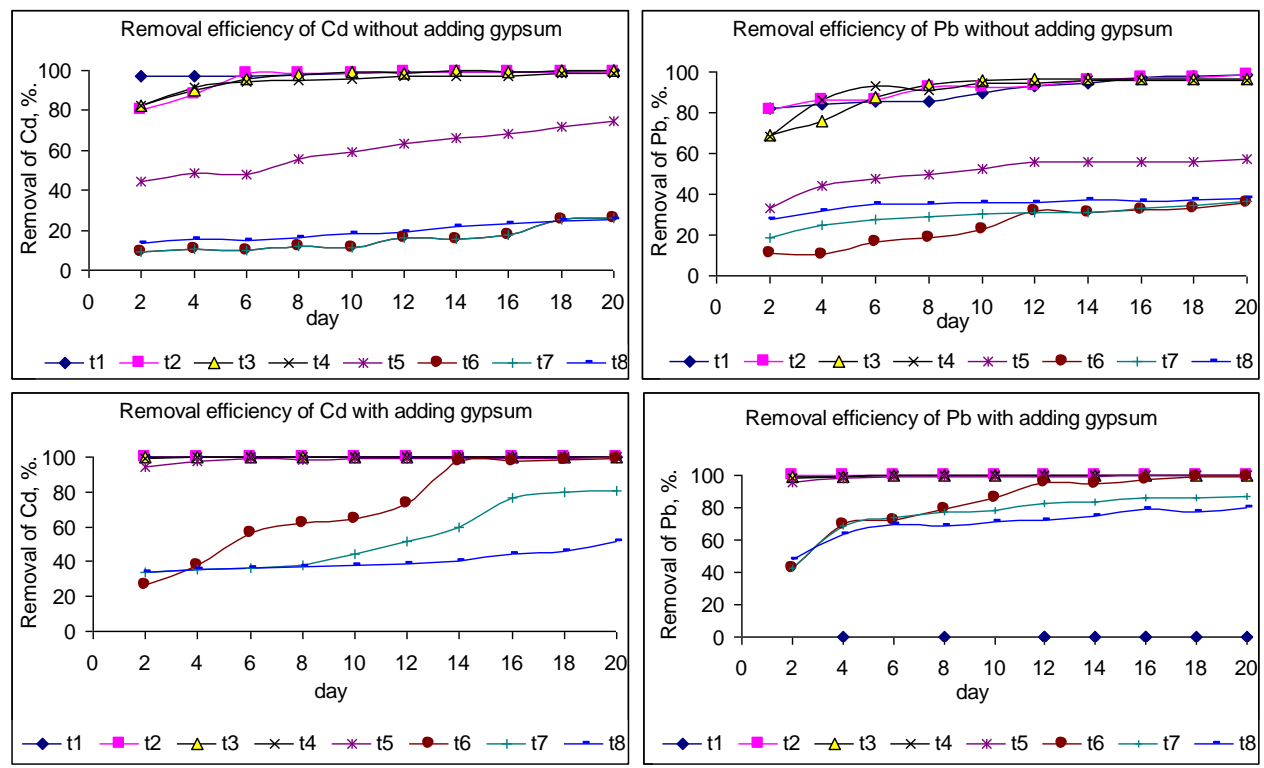

Fig. 3: Effect of fermentation time on removal efficiency of $\mathrm{Cd}$ and $\mathrm{Pb}$ for control and gypsum treatments.

On the other hand the removal efficiency increased with passing the fermentation time for the all treatments, especialy for the treatments which are possessing the low concentrations of the studied metals. This may be explained by the fact that sulphate reducing bacteria lost their activity under the high concentrations of $\mathrm{Cd}$ and $\mathrm{Pb}$, which were considered the toxicity limits for them. It was found that heavy-metal toxicity is one of the major causes of digester upset or failure (Swanwick et al., 1969). The toxic effect of heavy metals is attributed to disruption of enzyme function and structure by binding of the metals with thiol and other groups on protein molecules or by replacing naturally occurring metals in enzyme prosthetic groups (Vallee and Ulner, 1972). The most important methods for mitigating heavy-metal toxicity are precipitation, sorption and chelation by organic and inorganic ligands (Oleszkiewicz and Sharma, 1990). 


\section{Total solids (TS) and volatile solids (VS) for gypsum-treatments}

As be obvious in Fig. $4(\mathrm{a}, \mathrm{b})$ the TS values for all gypsum treatments decrease with the fermentation time and VS values agree with TS values in this trend for these treatments. Table (3) elucidates that, the removal percentage of TS and VS for all gypsum treatments increased with the increasing fermentation time and decreased with the increase in the initial concentration for both metals. The maximum values of removal efficiency were 90.1 and $81.7 \%$ for TS and VS, respectively at T1 (20 and 25 initial concentrations of $\mathrm{Cd}$ and $\mathrm{Pb}$, respectively). While the minimum values of removal efficiency were 73.1 and $58.6 \%$ at T8 (160 and 200 initial concentrations of $\mathrm{Cd}$ and $\mathrm{Pb}$, respectively). This trend may indicated that, the increasing initial concentration of the studied metals leads to decreasing bacteria species activity and rate of their growth, and then the rates consumption of TS and VS will be decreased. Anaerobic biological processes relying on the activity of SRB are being currently considered for the treatment of heavy metal containing effluents. The biogenic sulfides form insoluble complexes with heavy metals and result in their precipitation. However, heavy metals are inhibitory to anaerobic microorganisms, including methanogens and SRB. Therefore, heavy metals could have adverse effects on anaerobic microorganisms and hinder the performance of biological metal removal (karri et al., 2006).
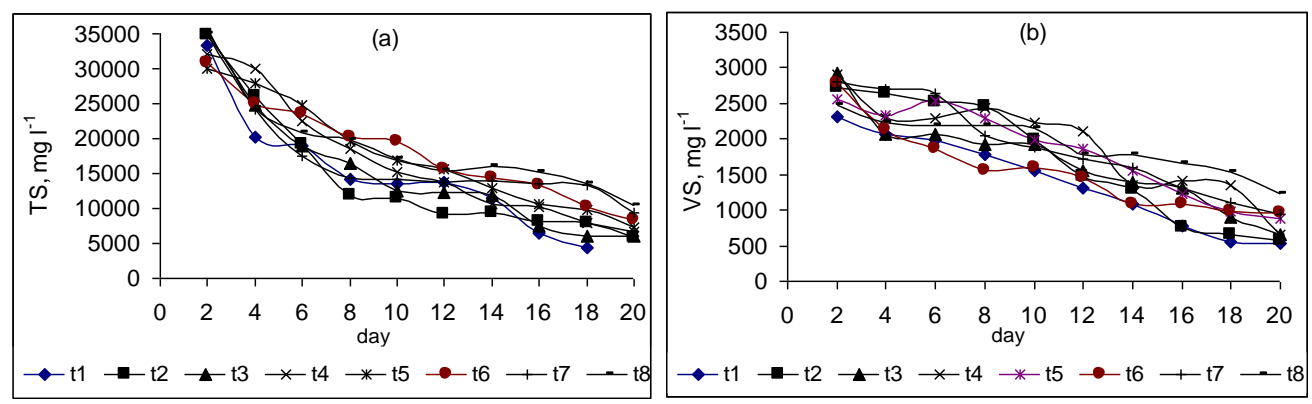

Fig. 4: The effect of fermentation time on the residual concentrations of total solids (TS) and volatile solids (VS) for gypsum treatments. 
Table 3: The removal percentage of total solids (TS) and volatile solids (VS) for gypsum treatments with the fermentation time

\begin{tabular}{|c|c|c|c|c|c|c|c|c|c|c|c|c|c|c|c|c|}
\hline \multirow[t]{2}{*}{ day } & \multicolumn{2}{|c|}{$\mathrm{T} 1$} & \multicolumn{2}{|c|}{$\mathrm{T} 2$} & \multicolumn{2}{|c|}{$\mathrm{T} 3$} & \multicolumn{2}{|c|}{$\mathrm{T} 4$} & \multicolumn{2}{|c|}{ T5 } & \multicolumn{2}{|c|}{ T6 } & \multicolumn{2}{|c|}{$\mathrm{T} 7$} & \multicolumn{2}{|c|}{$\mathrm{T} 8$} \\
\hline & $\mathrm{TS}$ & VS & $\mathrm{TS}$ & VS & $\mathrm{TS}$ & VS & $\mathrm{TS}$ & VS & $\mathrm{TS}$ & VS & $\mathrm{TS}$ & VS & $\mathrm{TS}$ & VS & $\mathrm{TS}$ & VS \\
\hline 4 & 48.4 & 30.2 & 33.4 & 10.5 & 36.6 & 29.8 & 23.0 & 22.4 & 28.4 & 20.7 & 35.9 & 28.1 & 37.9 & 8.1 & 37.5 & 24.1 \\
\hline 8 & 63.8 & 39.7 & 69.5 & 17.0 & 57.6 & 34.9 & 52.7 & 17.3 & 49.9 & 22.0 & 48.1 & 47.1 & 63.3 & 30.9 & 49.1 & 26.1 \\
\hline 10 & 65.2 & 47.1 & 70.9 & 32.9 & 68.0 & 34.9 & 61.2 & 24.1 & 56.7 & 32.5 & 49.8 & 45.8 & 63.4 & 35.9 & 56.4 & 27.5 \\
\hline 12 & 64.7 & 55.3 & 76.6 & 49.8 & 68.6 & 47.1 & 64.8 & 28.8 & 60.1 & 36.6 & 59.8 & 50.9 & 64.8 & 41.7 & 60.5 & 39.7 \\
\hline 18 & 88.6 & 81.0 & 79.8 & 78.0 & 84.4 & 69.6 & 79.6 & 53.9 & 74.9 & 66.8 & 74.1 & 66.8 & 65.9 & 62.4 & 65.1 & 47.8 \\
\hline 20 & 90.1 & 81.7 & 84.9 & 80.3 & 84.7 & 78.0 & 82.7 & 77.6 & 81.5 & 70.5 & 78.4 & 67.1 & 75.9 & 68.1 & 73.1 & 58.6 \\
\hline
\end{tabular}




\section{pH, sulphate and sulfide for the gypsum treatments}

Fig. (5) explains that, the $\mathrm{pH}$ values for all gypsum treatments were around to the neutral value ( $\mathrm{pH} 7)$. Since the change in $\mathrm{pH}$ values was not exceeded over 0.5 unit, this may be enhancing the conditions to the SRB growth. The $\mathrm{pH}$ value governed in the common form of sulphide in the media. Speece (1983) stated that only the undissociated H2S is capable of entering into the cell membrane. Later, it was shown that the bacteria have two threshold inhibition levels, first level for the undissociated H2S.

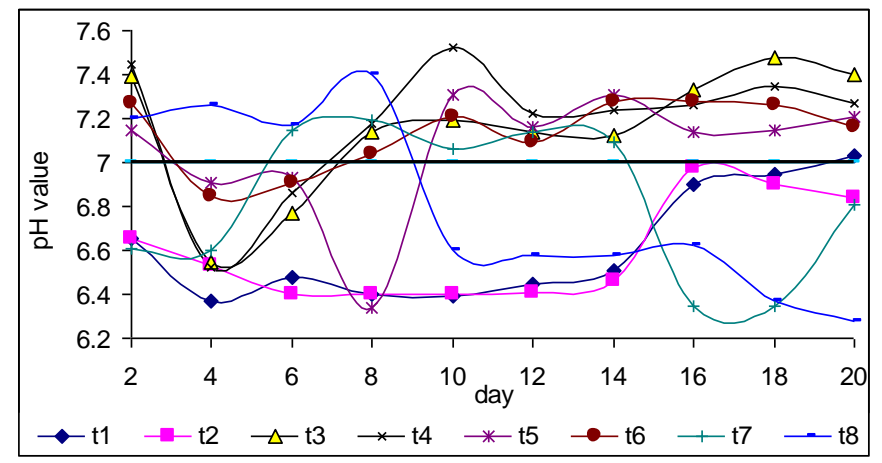

Fig. 5: $\mathrm{pH}$ values with the fermentation time for all gypsum treatments.

The second level for the total sulphide, which depends on the environmental $\mathrm{pH}$ value less than 7.2 and undissociated $\mathrm{H}_{2} \mathrm{~S}$ is dominant, which lead to reach the threshold limit. At a $\mathrm{pH}$ above 7.2, the total sulphide is responsible for the inhibitory effect. The sulphate reducing bacteria are less sensitive to total sulphide when the $\mathrm{pH}$ is increased from 6.8 to 8.0 and more sensitive to the undissociated sulphide concentration. Moreover, the $\mathrm{pH}$ increases lead to less concentration of undissociated $\mathrm{H}_{2} \mathrm{~S}$, which cause 50\% inhibition of growth (O'Flaherty and Colleran, 1998).

As shown in Fig. $6(a, b)$ the residual concentration of sulphate and sulfide in the gypsum treatments through the fermentation time (these concentrations were corrected via subtracting their values of control treatments from which). The decreasing sulphate concentration and the increasing sulphide concentration comparing with their initial concentrations at the initial time for all treatments indicate the occurrence of biological reduction process. Sulphate removal decreased after 20 days from 80.1 to $58.9 \%$ for $\mathrm{T} 1$ and $\mathrm{T} 8$, respectively. This indicated at high 
initial concentrations of the studied metals due to reduction in metabolic activity of SRB as a result of metal toxicity effect. The sulphide concentrations increased with the time until reached the maximum values then decreased with the time. This signifies that these concentrations transformed from soluble to precipitated forms such as $\mathrm{CdS}$ and $\mathrm{PbS}$. A large drop in sulfide concentration after day 2 was probably due to metal precipitating as insoluble sulfides and adsorption of sulfides onto the walls of the reactor (Jong and Parry, 2003).
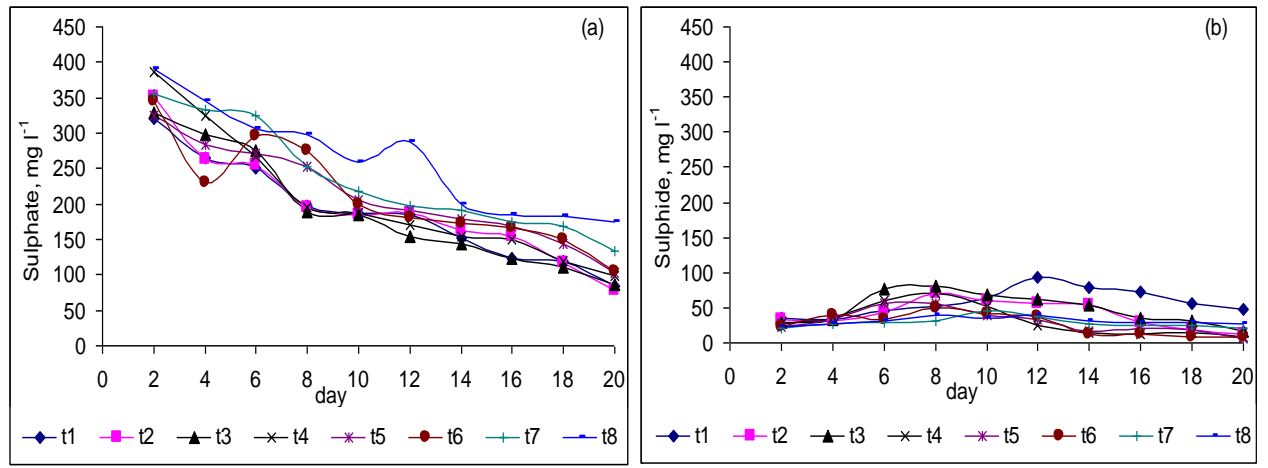

Fig. 6: Residual concentration of sulphate and sulfide with the fermentation time for the gypsum treatments.

The relations between the studied parameters among gypsum treatments

Table 4: Pearson Correlation $\mathrm{R}^{2}$ for some parameters among gypsum treatments.

\begin{tabular}{|c|c|c|c|c|c|c|c|c|}
\hline & $\mathrm{TS}$ & VS & $\mathrm{pH}$ & $\mathrm{Cd}_{\text {res }}$ & $\mathrm{Pb}_{\text {res. }}$ & $\mathrm{SO}_{4}^{-2}$ & $\begin{array}{c}\text { Total } \\
\text { sulphid }\end{array}$ & $\begin{array}{c}\text { Fermentation } \\
\text { time }\end{array}$ \\
\hline $\mathrm{TS}$ & 1 & $.852 * *$ & .076 & $.303 * *$ & $.427 * *$ & $.923 * *$ & .014 & $-.897 * *$ \\
\hline VS & $.852 * *$ & 1 & .095 & $.306 * *$ & $.356 * *$ & $.875^{* *}$ & $-.166-$ & $-.914 * *$ \\
\hline $\mathrm{pH}$ & .076 & .095 & 1 & .031 & .018 & $-.119-$ & $-.332 * *$ & .117 \\
\hline $\mathrm{Cd}_{\text {res. }}$ & $.303 * *$ & $.306 * *$ & .031 & 1 & $.937 * *$ & $-.450 * *$ & .192 & $-.237 *$ \\
\hline $\mathrm{Pb}_{\text {res. }}$ & $.427 * *$ & $.356 * *$ & .018 & $.937 * *$ & 1 & $-.528 * *$ & .219 & $-.324 * *$ \\
\hline $\mathrm{SO}_{4}^{-2}$ & $.923 * *$ & $.875^{* *}$ & $-.119-$ & $-.450 * *$ & $-.528 * *$ & 1 & .041 & $-.912 * *$ \\
\hline Total sulphide & .014 & $.166-$ & $-.332 * *$ & .192 & .219 & .041 & 1 & $-.250 *$ \\
\hline $\begin{array}{l}\text { Fermentation } \\
\text { time }\end{array}$ & $-.897 * *$ & $-.914 * *$ & .117 & $-.237 *$ & $-.324 * *$ & $-.912 * *$ & $-.250 *$ & 1 \\
\hline
\end{tabular}

** Correlation is significant at the 0.01 level.

* Correlation is significant at the 0.05 level.

res. $=$ residual concentration, $\mathrm{TS}=$ total solid, $\mathrm{VS}=$ =volatile solid. 
As be clear in Table (4) there are many significant relations between the studied parameters such as:

-TS with $\mathrm{SO}_{4}{ }^{-2}, \mathrm{VS}, \mathrm{Cd}$ and $\mathrm{Pb}$ as an order of positive relations and as an order of negative relation with fermentation time.

-VS with $\mathrm{SO}_{4}{ }^{-2}, \mathrm{Cd}$ and $\mathrm{Pb}$ as an order of positive relations and as an order of negative relation with fermentation time.

- $\mathrm{pH}$ with total sulphide as a negative relation.

- $\mathrm{Cd}_{\text {res }}$ with $\mathrm{Pb}_{\text {res }}$ as a positive relation and as a negative relation with each $\mathrm{SO}_{4}{ }^{-2}$ and fermentation time.

- $\mathrm{Pb}_{\text {res }}$ with $\mathrm{SO}_{4}^{-2}$ and fermentation time as negative relations.

- $\mathrm{SO}_{4}{ }^{-2}$ with the fermentation time as a negative relation

- Total sulphide with the fermentation time as a negative relation

The results in Table 4 confirm the previous obtained results.

\section{Kinetic studies}

Kinetic models of $\mathrm{Pb}$ and $\mathrm{Cd}$ reaction inside the reactors for control and gypsum treatments

$$
\begin{aligned}
& \mathrm{Pb}_{\mathrm{aq}}+\mathrm{Cd}_{\mathrm{aq}}----\mathrm{SRB}----\rightarrow \mathrm{Pb}_{\text {sulfides }}+\mathrm{Cd}_{\text {sulfides }} \\
& \mathrm{r}=\mathrm{k}\left[\mathrm{Pb}_{\mathrm{aq}}\right]^{\mathrm{a}}\left[\mathrm{Cd}_{\mathrm{aq}}\right]^{\mathrm{b}}
\end{aligned}
$$

Where aq is the total dissolved concentration (residual) of the metal in $\left(\mathrm{mgl}^{-1}\right), \mathrm{r}$ is the rate of reaction, $\mathrm{k}$ is the constant of the rate of reaction, $a$ is the order with respect to $\mathrm{Pb}_{\mathrm{aq}}, b$ is the order with respect to $\mathrm{Cd}_{\mathrm{aq}}$ and the overall order is $(a+b)$.

As it can be seen from Fig.7, the kinetic models for extrapolating, the rate of this reaction (2) indicate that the fitting of first-order models for each metal respect to both $\mathrm{Cd}_{\mathrm{aq}}$ and $\mathrm{Pb}_{\mathrm{aq}}$ with either gypsum or control treatments. Whereas the overall reaction must be the summation the orders of $\mathrm{Cd}$ and $\mathrm{Pb}$ and then the overall reaction became second order $(\mathrm{r}=2)$. Thus, $\mathrm{k}$ in this case defines by $k 2$ nd, which called a second-order rate constant. The units of $k 2$ nd are found to be conc. ${ }^{-1}$ time $^{-1}$. These results indicated that the rate constant of this reaction depended on the initial concentrations of the reactants $(\mathrm{Cd}$ and $\mathrm{Pb})$. Thus, this result supported the above results in this work, i.e. the increasing of initial concentration of the studied metals leads to decreasing the ability of their removal because of limiting of the producing sulphide. 

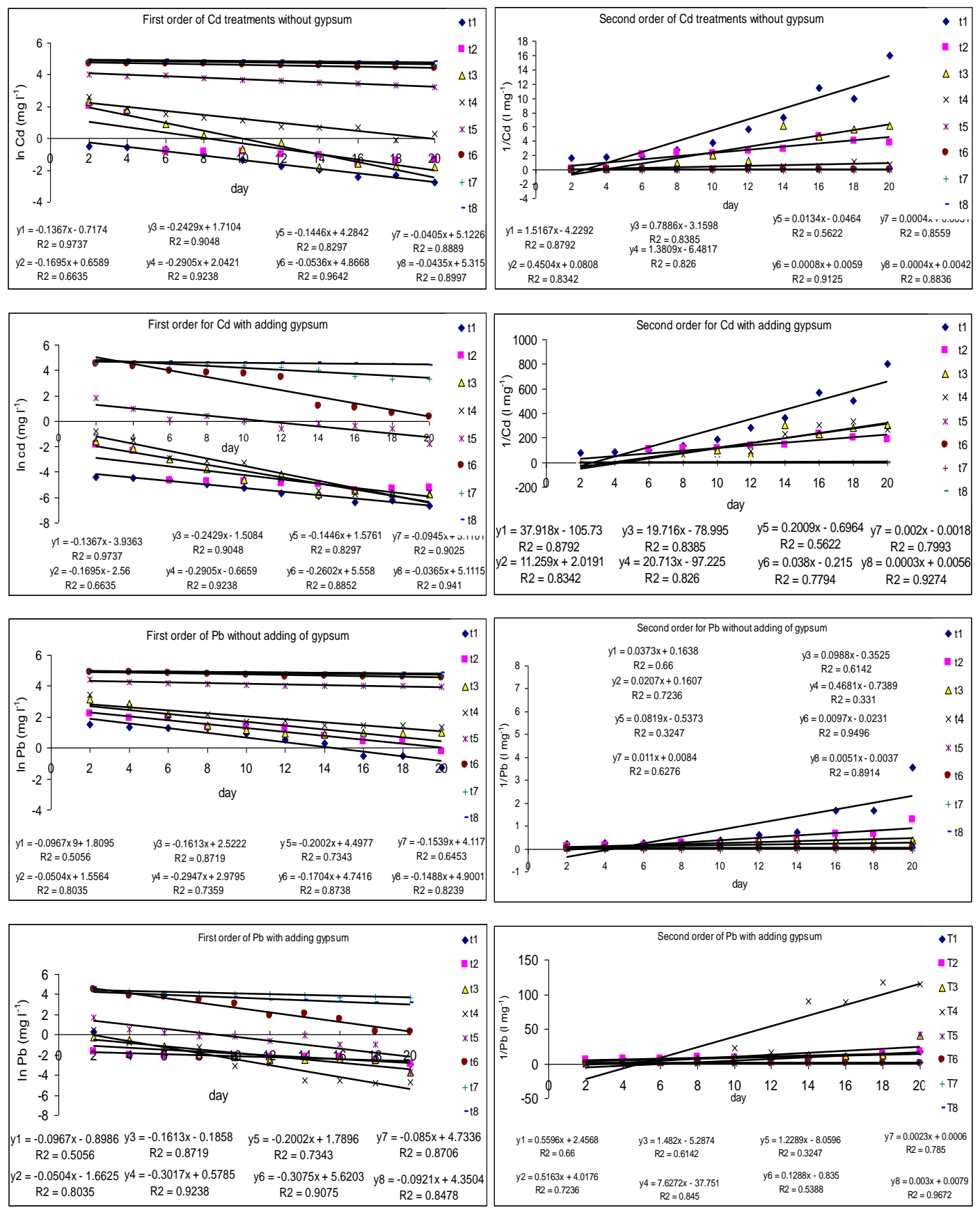

Fig. 7: Kinetic models of $\mathrm{Cd}$ and $\mathrm{Pb}$ residuals with the fermentation time for control and gypsum treatments. 


\section{SEM with EDX analysis}

Fig. (8, a) shows SEM micrograph of $\mathrm{Cd}$, and $\mathrm{Pb}$ precipitates on the solid residues after the interaction between the slurry components with $\mathrm{Cd}$ and $\mathrm{Pb}$ for control treatment. Whereas Fig. $(9, \mathrm{a})$ shows SEM micrograph of $\mathrm{Cd}$, and $\mathrm{Pb}$ precipitates on the solid residues after the interaction between the slurry components with $\mathrm{Cd}$ and $\mathrm{Pb}$ for gypsum treatment. It can be seen in the photomicrograph of gypsum treatment increasing of distribution and scattering of these precipitates (white arrow reveals the metal ion precipitates) over than control treatment. Fig. $(8, \mathrm{~b})$ shows EDX spectrum of the residue of control treatment, the average elemental content of which was $58,93 \% \mathrm{O}, 3.34 \% \mathrm{Al}, 11.16 \% \mathrm{Si}, 21.05 \% \mathrm{~S}, 3.50 \%$ $\mathrm{Fe}, 0.30 \% \mathrm{Cd}$ and $0.46 \% \mathrm{~Pb}$. Whereas Fig. $(9, \mathrm{~b})$ shows EDX spectrum of the residue of gypsum treatment, the average elemental content of which was $44.76 \% \mathrm{O}, 3.76 \% \mathrm{Al}, 9.50 \% \mathrm{Si}, 35.12 \% \mathrm{~S}, 3.59 \% \mathrm{Fe}, 1.17 \%$ $\mathrm{Cd}$ and $2.10 \% \mathrm{~Pb}$. Comparison between the two cases demonstrates the effect of adding gypsum on the degree of the removal of these metals and the form of their precipitation as a sulphides.

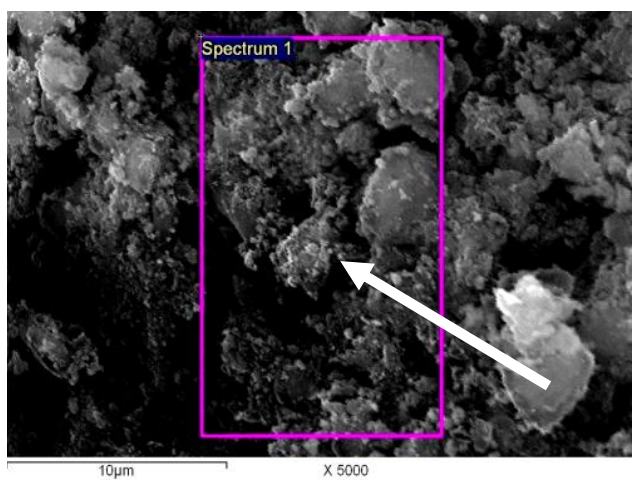

(a)

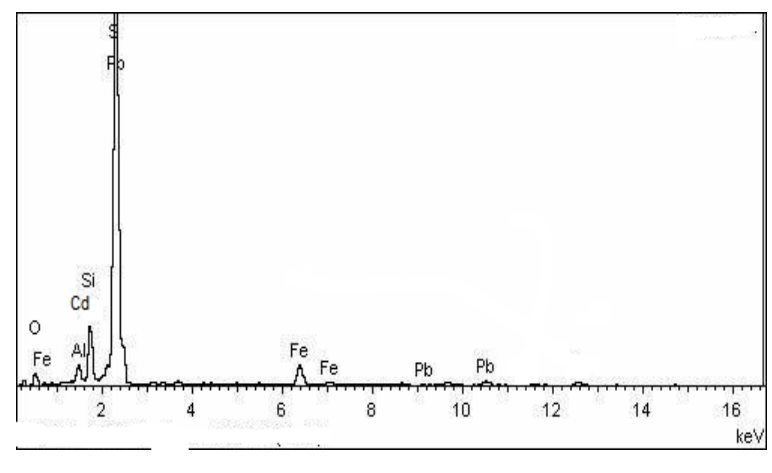

(b)

Fig. 8: SEM (a) and EDX (b) of the residue of control treatment. 


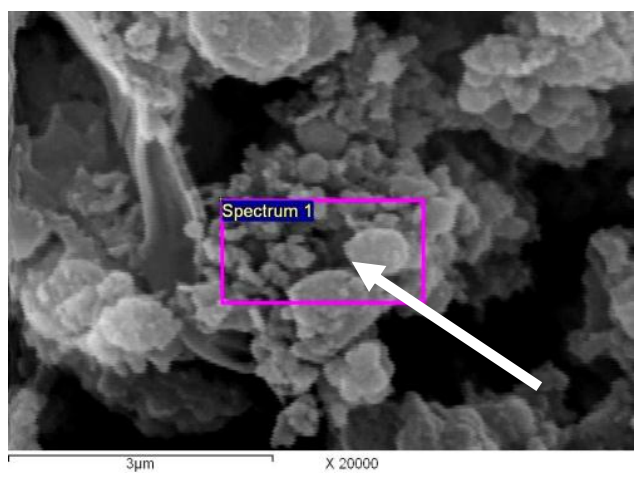

(a)

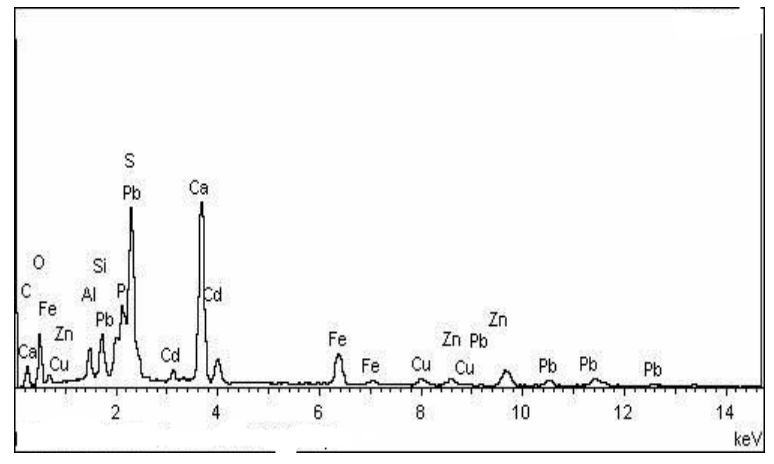

(b)

Fig. 9: SEM (a) and EDX (b) of the residue of gypsum treatment.

\section{CONCLUSION}

\section{From this study the following conclusion can be drawn as:}

- The removal efficiency level for both $\mathrm{Cd}$ and $\mathrm{Pb}$ metals increased with the decrease in the initial concentrations for all treatments. This level was $>99 \%$ for gypsum treatments when $\mathrm{Cd}$ and $\mathrm{Pb}$ initial concentrations were not exceed over 120 and $150 \mathrm{mgl}^{-1}$ (T6), respectively. By comparison, these levels for control treatment were (>99\% for $\mathrm{Cd}$ and $98.9 \%$ for $\mathrm{Pb}$ ) when the initial concentrations of $\mathrm{Cd}$ and $\mathrm{Pb}$ were not over 60 and $75 \mathrm{mgl}^{-1}$ (T3), respectively.

- The $\mathrm{pH}$ values for all gypsum treatments were around to the neutral value $(\mathrm{pH} 7)$ this may be due to enhancing the optimum conditions for the growth of the SRB.

- The removal percentage of either TS or VS for all gypsum treatments increased with increasing the fermentation time and decreased with the increasing the initial concentration for both metals. The maximum values of removal efficiency were 90.1 and $81.7 \%$ for TS and VS, respectively at $\mathrm{T} 1$ (20 and $25 \mathrm{mgl}^{-1}$ initial concentrations of $\mathrm{Cd}$ and $\mathrm{Pb}$, respectively). While the minimum values of removal efficiency were 73.1 and $58.6 \%$ at $\mathrm{T} 8$ (160 and $200 \mathrm{mgl}^{-1}$ initial concentrations of $\mathrm{Cd}$ and $\mathrm{Pb}$, respectively).

- The kinetic models indicated the fitting of first-order models for each metal respect to both $\mathrm{Cd}_{\mathrm{aq}}$ and $\mathrm{Pb}_{\mathrm{aq}}$ with either gypsum or control 
treatments. But the overall reaction must be the summation of the orders of $\mathrm{Cd}$ and $\mathrm{Pb}$ and then the overall reaction became second order $(\mathrm{r}=2)$. This indicated that the rate constant of this reaction depended on the initial concentration of the reactants $(\mathrm{Cd}$ and $\mathrm{Pb})$.

- The EDX spectrum of the residue of control treatment, the average elemental content was 58,93\% O, 3.34\% Al, $11.16 \% \mathrm{Si}, 21.05 \% \mathrm{~S}$, $3.50 \% \mathrm{Fe}, 0.3 \% \mathrm{Cd}$ and $0.46 \% \mathrm{~Pb}$. While the EDX spectrum of the residue of gypsum treatment, the average elemental content were $44.76 \%$ $\mathrm{O}, 3.76 \% \mathrm{Al}, 9.50 \% \mathrm{Si}, 35.12 \% \mathrm{~S}, 3.59 \% \mathrm{Fe}, 1.17 \% \mathrm{Cd}$ and $2.10 \% \mathrm{~Pb}$. Comparison between the two cases elucidates the effect of adding gypsum on the degree of the removal of these metals and the form of their precipitation as a sulphide.

\section{REFERENCES}

Al-Asheh, S. and Duvnjak, Z. (1998). Binary metal sorption by pin bark: study of equilibria and mechanisms. Sep. Sci. Techno. 33: 1303-1329.

Alvarez, M. T.; Crespo, C. and Mattiasson, B. (2007). Precipitation of $\mathrm{Zn}(\mathrm{II}), \mathrm{Cu}$ (II) and $\mathrm{Pb}$ (II) at bench-scale using biogenic hydrogen sulfide from the utilization of volatile fatty acids. Chemosphere 66 (9): 1677-1683.

APHA (1980). Standard Methods for the Examination of Water and Wastewater, Method 426 C, $15^{\text {th }}$ edition. American Public Health Association, Washington, D.C.

APHA (1992). Standard Methods for the Examination of Water and Wastewater, $18^{\text {th }}$ edition. American Public Health Association, Washington, D.C.

Fischer, E. (1883). Bildung von Methylenblau als Reaction auf Schwefelwasserstoff. Chem. Ber., 26: 2234-2236. 
Gammons, C. H. and Frandzen, A. K. (2001). Fate and transport of metals in $\mathrm{H}_{2} \mathrm{~S}$-rich waters at a treatment wetland. Geochemical Transactions 2: $1-15$.

Ho, Y. S.; Ng, J. C. Y. and McKay, G. (2001). Removal of lead (II) from effluents by sorption on peat using second-order kinetics. Separation Science and Technology 36: 241-261.

\section{http://www.jeolusa.com}

Jong T. and Parry, D. L. (2003). Removal of sulfate and heavy metals by sulfate reducing bacteria in short-term bench scale upflow anaerobic packed bed reactor runs. Water Research. 37: 3379-3389

Karri, S.; Sierra-Alvarez, R. and Field, J. A. (2006). Toxicity of copper to acetoclastic and hydrogenotrophic activities of methanogens and sulfate reducers in anaerobicsludge, Chemosphere 62: 121-127.

Lagergren, S. (1898). Zur theorie der sogenannten adsorption geloster stoffe. Kungliga Svenska Vetenskapsakademiens. Handlingar, 24 (4): 1-39.

O'Flaherty, V. and Colleran, E. (1998). Effect of sulphate addition on volatile fatty acid and ethanol degradation in an anaerobic hybrid reactor. I: process disturbance and remediation. Bioresource Technology. 68: 101-107.

Oleszkiewicz, J. A. and Sharma, V. K. (1990). Stimulation and inhibition of anaerobic process by heavy metals - a review. Biol. Wastes 31 : 45- 67.

Postgate, J. R. (1984). The sulphate reducing bacteria. Cambridge University Press, Cambridge. 
Shin, H. S.; Oh, S. E. and Lee, C. Y. (1997). Influence of sulfur compounds and heavy metals on the methanization of tannery wastewater. Water Sci. Techno. 35 (8): 239-245.

Skoog, D. A.; West, D. M. and Holler, F. J. (1992). Fudamentals of Analytical Chemistry. Saunders College Publishing, Fort Worth, USA

Speece, R. E. (1983). Anaerobic biotechnology of industrial wastewaters. Environmental Science and Technology. 17: 416A427A.

Swanwick, J. D.; Shurben, D. G. and Jackson, S. (1969). A survey of the performance of sewage sludge digesters in Great Britain. J. Water Pollut. Control Fed. 68: 639-653.

Vallee, B. L. and Ulner, D. D. (1972). Biochemical effects of mercury, cadmium, and lead. Annu. Rev. Biochemic. 41: 91-128.

Wase, D. A. J. and Forster, C. F. (1995). Batch nickel removal from aqueous solution by Sphagnum moss peat. Water Res. 29: 13271332.

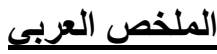

أزالة الكادميوم والرصاص والحمل العضوي من مياه الصرف الصحي باستخدام

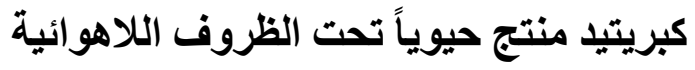

عفاف احمد عبد الرازق" محمد علي عبد الهادي"**

تحمل مياه الصرف الصحي الغير معالجة في محطات الصرف الصحي بالأسماعيلية ـ مصر العديد من الملوثات خصوصاً المعادن الثقيلة مثل الرصاص و الكادميوم حيث لايوجد فصل بين بين

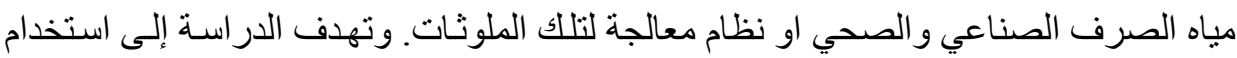

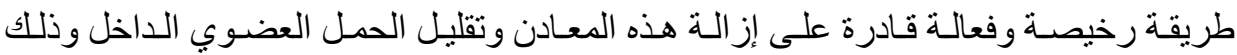
باستخدام الهضم اللاهو ائي.

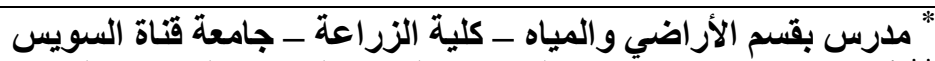

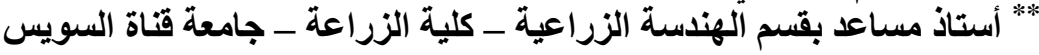


لذا أجريت دراسـة معمليـة في الوحدة التجريبية للغـاز الحيوي بقسم الهندسة الزراعية ـ كليـة

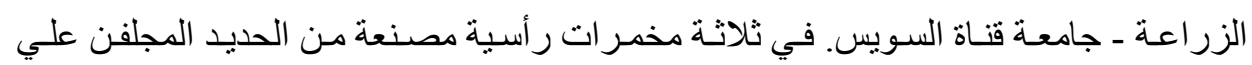

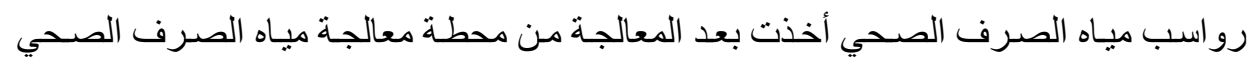

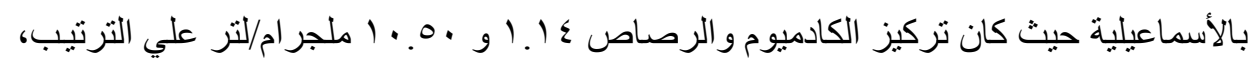

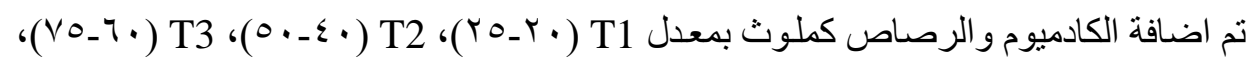

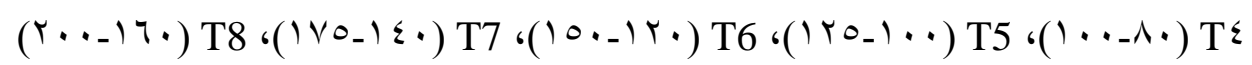

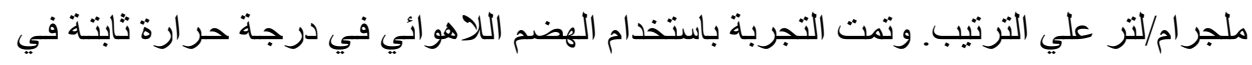

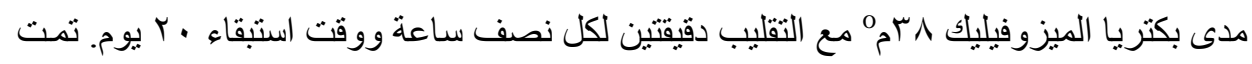

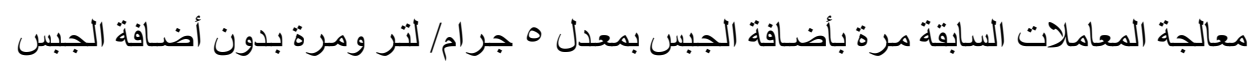
ككنترول.

تم قياس كلَ من معدل أز الة الكاديوم والرصـاص، نسبة از الذة لمـادة العضوية في صورة مو ادة

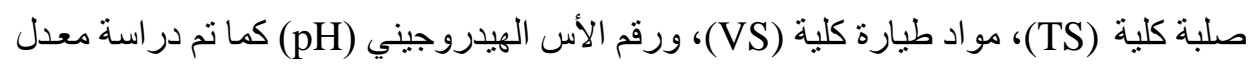

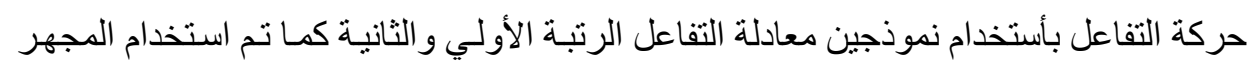

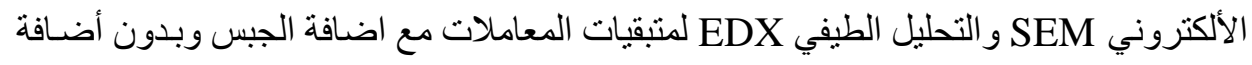

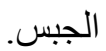

\section{وقد اظهرت النتائج ما يلي:-}

ـ أزداد مستوي كفاءة إز الة كلُ من الكادميوم و الرصاص مع قلة التركيز ات الأوليـة لهمـا مـع كل المعاملات .وكان مستوي الأز الة اكبر من \% 99مع معاملات الجبس لتركيز ات الأولية للكادميوم

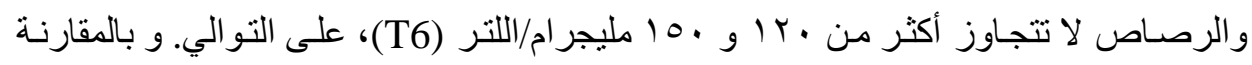

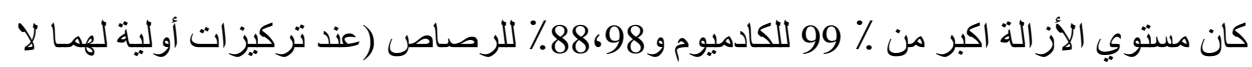

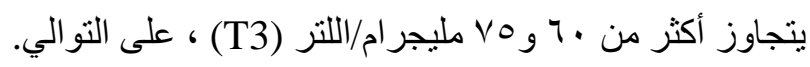

ـ كانت قيم رقم الأس الهيدروجيني (pH) لجميع معاملات الجبس حول درجـة الحموضـة

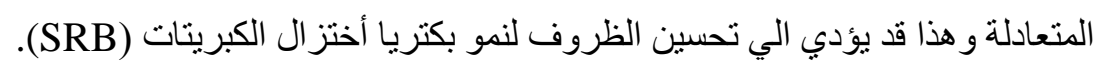

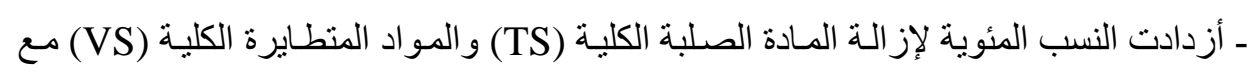

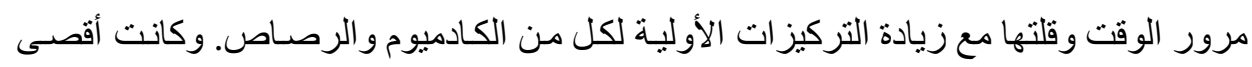

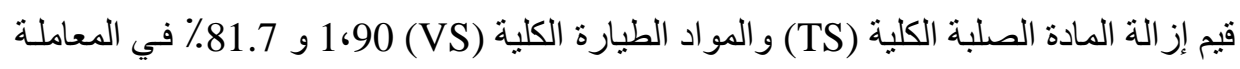

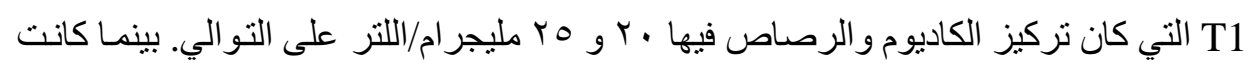

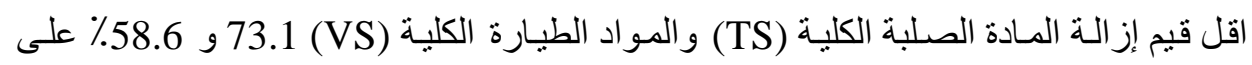


التو الي في المعاملة T8 التي كان تركيز الكاديوم و الرصـاص فيها ـ ا 1 و . . ب مليجرام/اللتر على التوالي.

ـ تم التوصل من دراسـة حركة التفاعل الي مو افقة الرتبـة الثانيـة لهذا التفاعل سواء لمعاملات الكنترول او معاملات الجبس.

ـ دل استخدام المجر الأكتروني SEM و التحليل الطيفي EDX الي ان اضافة الجبس أدت الي زيادة مترسبات تللك العناصر في صورة كبريتدات.

لذا توصي الدراسة بأستخدام تلك الطريقة لمعالجة تلك الملوثات مع تقليل الحمل العضوي ومن

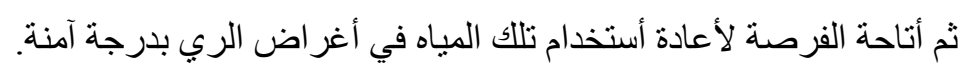

